UDC 811.111

DOI https://doi.org/10.32838/2663-6069/2020.1-2/28

\author{
Mykhaylenko $V . V$. \\ King Danylo University
}

\title{
IT-PRONOUN: CONTEXT CORRELATION
}

The present paper is a corpus study of the it-pronoun in the author's discourse and its correlation with context. The interpretation of the 3rd person singular pronoun either in the sentence, or in the discourse is the most controversial phenomenon. The scholars put forward various principles of its classification though they all cause confusion - one and the same use of the it-pronoun can be referred to different groupings. We attempted to introduce an evolutionary principle that heped us to sort out some vague cases while others revealed a functional semantic typology. Naturally, the investigation must be based on the non-professional (like fiction) and professional (like economics or legal) discourse, where vagueness is contraindicative.

The British National Corpus defines it-frequency - 1045013 per $100 \mathrm{ml}$ words in the English language which testifies to our hypothesis that the higher frequency of the item the higher possibility to refer to a functional or auxiliary part of speech, of the frequency of the indefinite article a is 213 692; the particle to - 2565 070, the prposition on - 1914 216, etc. Though most grammarans refer the personal pronoun (it including) to the notional parts of speech on the basis of the declinable form, syntactical function, lexical-grammatical valency, and a specific 'referential' function in the sentence. We consider that it-pronoun has a complicated functional semantics. And the actualization of the definite function depends on its context. No doubt that the number of its function much depends upon the scholar's scope of his/her information or intuition. But it needs a great number of investigation to determine its functional typology employing a corpus analysis. The vagueness of its functional semantics in fiction can be explained by the genre requirements, however, such vagueness may cause much grave misunderstanding in the professional discourse which demands a clear-cut definition

Key words: it-pronoun, semanticaly 'empty' word, functional substitute, contextual semantics, discourse.

Preliminaries. The British National Corpus defines it-frequency - 1045013 per $100 \mathrm{ml}$ words in the English language which testifies to our hypothesis that the higher the frequency of the item the higher possibility to be a functional or auxiliary part of speech, cf the frequency of the indefinite article $a$ is 213692 ; the particle to -2565070 , the prposition on - 1914 216, etc. Though most grammarans refer the personal pronoun (it including) to the notional parts of speech on the basis of the declinable form, syntactical function, lexical-grammatical valency, and a specfic 'referential' function in the sentence. The latter devides the scholars into several groups which depend on the school they belong to. According to its name a prononun or a pronominal stands for a noun and shares with it grammatical categories that makes them to be two sets of one lexical-grammatical class. Most scholars are in two minds to recognize or reject the common meaning. Besides, pronoun can stand as well for a phrase, a clause, a sentence, and a situation expressed in the preceding fragment of text/discourse.

The class of English pronouns includes units like he, she, it, us, they, her, herself, ourselves, each other, here, there, now, someone, somewhere, this, that and these which constitute a closed class, their semantics includes the basic features - case, number, gender and person. Quirk et al define the pronoun as a part of speech, but despite its pronominal nature they include it into a close part of speech paradigm "close in the sense that they are only exceptionally extended by the creation of additional members" alongside with other functional unchancheable parts of speech [18, p. 67-68; 15, p. 91]. Despite Sapir's definition that a word must have a meaning in our case it is a lexical one, basic factor. Actually, the 3rd-person pronoun does not actualise but acquires it from the correferential unit.

Sapir writes thathe term ' 3 rd person singular pronoun receives its meaning from i' has a long time tradition in linguistic theory and it is undoubtedly a useful description of elements such as 'he', 'she' and 'they', found in all West-European languages the notion 'third person' is much more troublesome. In his Philosophy of Grammar Otto Jespersen argues against the definition of third person as 'the person or thing being talked about' because also the first 
and second person are captured by this definition $[20$, p. $35 ; 11$, p. 212$]$

"It" as well as "he' and "she "are ambiguous pronouns because every time used in sentence or discourse they coreferate with their antecedent a noun, a noun phrase, a clause or a situation expressed in the preceding text ora discourse

It has long been recognised that Old English personal pronouns often turn up in 'special' positions, i.e. positions in which functionally equivalent nominals do not occur. Regardless of the particular syntactic analysis given to these specially placed pronouns, it is generally assumed that their special placement is a freely available option. Focusing on object personal pronouns in a large corpus of Old English prose, this paper finds clear evidence of a correlation between the option of special placement on the one hand and pronoun case on the other. For pronouns governed by a preposition in particular, I show that this correlation holds independently of the particular preposition involved and of the PP's semantics. For pronouns governed by a verb, I find that the effect appears to be mediated by information structure considerations. The present paper is focused on the IT-3-rd person pronoun, its distribution, contextual semantics and, and functions in the sentence and the discourse. Accordingly, the primary object of this investigation is the IT-pronoun in the Old English poem "Beowulf" and the modern English novel "Angels \& Demons" by Dan Brown from which we retrieved the text fragments (100 pages) to compile our corpus of IT-units.

Theoretical background. One of the features that makes pronouns a special class of linguistic items is the way in which they contribute to the meaning of sentences (or other constructions in which they occur) [21, p. 2]. The term 'pro-form' was probably first used by Jerrold Katz and Paul Postal (1964) as a mechanism to explain both syntactic and semantic aspects of the substitutions. Syntactically, the pro-constituent guarantees the recoverability of a substitution or deletion [12]. From the semantic point of view, the pro-form calls for interpretation by retrieving its equivalents. Since its introduction the term pro-form has often been used alternately with pronoun, and now it seems to replace pronoun. However, some linguistic elements seem to have comparable properties to pronouns but they are not substitutes for nouns. In fact, there are many other classes of words than nouns that get a different form in the following mention in a text. In linguistics, a pro-form is generally taken as an element used in place of other linguistic element(s). Pronouns are the most common pro-forms or null pronouns [19] used to substitute for a noun or a noun phrase $[18$, p. $75-74]$.'She', for example, is a third-person singular pronoun used in place of a singular human female animate noun such as a woman as in, 'A woman is coming to see you. She has called you earlier.' Although pronouns have often been used as examples of pro-forms, there are other linguistic elements that have comparable properties but do not substitute for a noun or a noun phrase. 'So', as in 'He thinks it will rain tonight but I don't think so,' substitutes for a whole clause, i.e. 'it will rain'. Here and there are pro-forms. Moreover, there are some other terms that are loosely used in place of pro-forms. One of these is ellipsis which can be considered as a process by which redundant information in a sentence is omitted, whereas prop-forms, however, are not omissions.

Lyons criticized this view on two points, first that it should read 'noun phrase' instead of 'noun' and second: 'to say that pronouns are primarily substitutes $\langle\ldots\rangle$ is to imply that their anaphoric function is more basic than their deictic function. [But] it is deixis that is the more basic of these two kinds of pronominal reference' [14, p. 637]. $\mathrm{He}$ admits that it is nonsensical to analyse them as substitutes for the linguistic expression 'the speaker' or 'the hearer'. If there is a need to clarify this debate the notion of the level of analysis, must be stated in information-structural terms [19] or a deictic word on the communicative level and a substitution on the functional level, we can go on enumerating some other levels and the scopes of analysis: phrase, sentence, and discourse. Lost in the tenets of theoretical discussions scholars forget the object itself which does not change, it is the context that changes as well as tools of analysis. And due to the it-context we can decode its functional semantics. The fact is that originally the personal pronouns did not have their lexical meaning - this is the starting point of the search of their meanings uses of ' $I$ ' and 'the speaker' show a remarkable complementary distribution: ' $\mathrm{I}$ ' is used to refer to the person that is uttering the word 'I' [see 16, p.32]. We would like to remind that the $3^{\text {rd }}$-person singular pronouns have been grammaticalized into gender markers of the noun. Accordingly, the gender of antecedents of anaphoric pronoun is often determined by the gender of the pronouns [17, p. 604]. The speaker' on the contrary is used to refer to another speaking person, not the one who is uttering the words 'the speaker'. But the opponents of the substitution theory stress that it-is a true substitution [see 23; cf. 21, p. 113]. 
If the 3rd-person pronoun and the like "used in the grammatical classification of words, referring to the closeset of items which can be used to substitute for a noun phrase (or single noun)." Then there must be a flaw in the traditional classification into parts of speech. We suggest that they can form a specific field of words based on the peripheries of pronominals constituents noun class of traditional pronun class, noun, adjective, verb. The fact is that there used to be various attempts to distribute, for instance, pronouns between noun and adjectives. However, very few scholars would endeavour to break a two-thousand old-aged pyramid of parts of speech.

Corpus analysis and discussion. It has long been recognised that Old English personal pronouns often turn up in 'special' positions, i.e. positions in which functionally equivalent nominals do not occur. Regardless of the particular syntactic analysis given to these specially placed pronouns, it is generally assumed that their special placement is a freely available option. Focusing on the object - personal pronouns in a large corpus of Old English prose, this paper finds clear evidence of a correlation between the option of special placement on the one hand and pronoun case on the other. For pronouns governed by a preposition in particular, we can illustrate that this correlation holds independently of the particular preposition involved.

Within the pronominal system of Old English the 3 p. sg. neuter anaphoric pronoun 'hit' occupies a special place [1, p.455]. In some Old English texts it is represented by its h-less variant, i.e. 'it-3rd-person pronoun.

\begin{tabular}{|c|c|c|c|c|}
\hline & Masculine & Neuter & Feminine & Plural \\
\hline Nominative & hē (he, it) & \multirow[t]{2}{*}{ hit (it) } & hēo (she, it) & \multirow[t]{2}{*}{ hìe (they) } \\
\hline Accusative & hine & & hìe & \\
\hline Genitive & \multicolumn{2}{|c|}{ his } & \multirow[t]{2}{*}{ hire } & hira \\
\hline Dative & \multicolumn{2}{|c|}{ him } & & him \\
\hline
\end{tabular}

Hogg admits that the third person system can be confusing when confronted with actual text, even though the paradigm above looks quite simple: some case forms are identical [8, p.22].

There are some examples retrieved from "Beowulf" which further on will develop into the Modern English standard anaphoric "it", for instance:

1. hú hit Hring-Dene the Ring-Danes"

æfter béorpege gebún hæfdon." how it, was (115-117)

2. Gewát ðá néosian sybðan niht becóm hú hit Hring-Dene

"He then went to visit and see the high house when night came' how it, the Ring-Danes"(272)

The referred thesis finds its proof in the Modern English practice, cf: the Old English text fragments with those of the Modern parallel text. We have also determined the root of the modern English' demonstrative it' in the Beowulf parallel text, see:

3. Ic pæt gehýre pæt pis is hold weorod fréan Scyldinga $\cdot \mathrm{I}$ hear it, that this is a legion loyal to the lord of the Scyldings (290-291).

4. hwén' ic pæt hé wille gif hé wealdan mótI expect that he will wish, if he can compass it (428-430).

5. secgað saélíðend pæt pæs sele stande "it is said by sea-farers that in this hall stands,.. (411-412).

6. ic pæt ponne forhicge swá mé Higelác síe mín mon drihten then I it scorn 'so that for me Hygelac may be' (435-435).

7. pá pæt hornreced healdan scoldon ealle búton ánum - pæt wæs yldum cúp. pæt híe ne móste. "they that the horned-house were obliged to guard "all but one - it was known to men".

In the given illustrations Old English poet is rendered into Modern English as "it" in the demonstrative function. Let's compare the case forms of Masculine and Neuter

Nominative pæt - se

Accusative pæt - pone

Genetive pæs $-\mathrm{N}=\mathrm{M}$

Dative pæm $-\mathrm{N}=\mathrm{M}$

The Genetive and Dative case forms coincide with those in the Neuter singular [8, p. 19;2;9].

Consequently, there is a difficulty of differentiating the gender of paet and its forms in the Old English text [23]. We can also illustrate the emphatic (or cleft) construction retained into Modern English:

8. péoden Hróðgár, pæt ic pé sóhte for pan híe mægenes cræft "míne cúpon·selfe ofersáwon "sovereign Hrothgar it were thee I should seek for that they the force of the strength of mine knew" (417-418) "for that they the force of the strength of mine knew; themselves had looked on"

In our Modern English corpus retrieved from the novel "Angels and Demons" by Dan Brown we can keep on the classifying "it" in the Modern English sentence [see 24; 25; 7, p. 337] and discourse structure used:

(i) As a formal subject:

1. Jogging to keep up with Kohler's electric wheelchair as it sped silently toward the main entrance 
2. Building $\mathrm{C}$ appealed to Langdon's sense of architectural style - conservative and solid. It had a red brick facade,

(ii). As a demonstrative pronoun:

3. Sighing, he scooped up the paper and looked at it.

4. The Illuminate history was by no means a simple one. I'll freeze to death trying to explain it.

5. The cabin itself looked surprisingly like a wide-body commercial airliner. The only exception was that it had no windows.

6. I suspect you and I will understand each other perfectly, Mr. Langdon.

Somehow Langdon doubted it.

(iii) As an impersonal pronoun with nouns denoting time, distance, weight, weather, etc.):

5. It's five o'clock in the morning!

6. Robert Langdon dashed down the stairs outside the church and into the middle of the piazza. It was getting dark now, the springtime sun setting late in southern Rome

(iv) As an introductory or anticipatory item (introducing a real subject):

7. It would be a shock no child deserved.

8. It depends whom you represent,

(v) As an emphatic item:

9. known behind his back as Konig - King. It was a title more of fear than reverence for the figure

10.if there was one recurring theme, it was that science and religion had

been oil and water.

(vi) In the tag of a disjunctive question:

11.Flying's not a problem for you, is it, sir?"

As one can perceive the principles are far from being homogeneous, group (i) and group (iv) which based on the syntactical function of "it" in the sentence structure; group(iii) based on the type of the sentence, and groups (ii; v) are based on the communicative principles [21]. Jacobs considers them pronominals in the referential function [10, p. 117-118, 6, p. 241]. Carter et al. write that these pronominals retain their part of speech status though the scholars avoid this classificatory feature and introduce the phrase "we use", see: "we use personal prononuns in place of noun phrases," but such phrase signifies the pronoun auxiliary or suplementary status of the noun [3, p. 420-421]. Eastwood classifes the pronuns into aseparate class but points out the deictic function of the personal pronouns: "we use them 'for the speaker (I) and the person spoken to (you), as for the 3 rd person singular (he) refers them to other people or things, i.e. they are employed in the referential function and the context reveals their meaning [5, p. 233-234]. All these definitions have the same disadvantage - different levels of the investigation. We believe that Heuser's classification of the personal pronouns in the 3rd person is worth mentioning as it reflects current approaches to the eternal phenomenon $[13$, p. $120-121]$ :

(a) deictic pronouns (in the referential function) in the sentence or text/discourse continuum; (b)'lazy' pronouns (in correferential function) in the text continuum;

(c) bound pronouns (in the introductory or anticipatory function; (d) e-type pronouns (in the quantifying function) in the frame: and (e) functional pronouns.

In our opinion the 3 rd person singular pronoun is used as a structural component of discourse which can be treated as "dummy," - a grammatical unit that has no meaning, but completes a sentence to make it grammatically complete -the word lack any semantically independent meaning or a substitute word, which refer back to a previously occurring element of structure, are also often called prop words, grammatical [4, p. 158], "substitute words" "null constructions" or "empty" because they need an immediate context to make their interpreting possible in the text/discourse continuum. The term 'pro-form' was probably first used by Jerrold Katz and Paul Postal (1964) as an instrument to explain both syntactic and semantic aspects of the substitutions in the above examples [12]. Syntactically, the pro-constituent guarantees the recoverability of a substitution or deletion. All these terms refer to one and the same phenomenon like, 3rdperson pronouns, one, thing, do, so, etc. "which refer back to a previously occurring element of structure" [4, p. 392].

Findings and perspective. We consider that it-pronoun has a complicated functional semantics. And the actualization of the definite function depends on its context. No doubt that the number of its function much depends upon the scholar's scope of his/her information or intuition.

But it needs a great number of investigation to determine its functional typology employing a corpus analysis.

The vagueness of its functional semantics in fiction can be explained by the genre requirements, however, such vagueness may cause much grave misunderstanding in the professional discourse which demands clear-cut definitions 


\section{References:}

1. Alcorn Rhona. Pronoun placement and pronoun case in Old English. Neuphilologische Mitteilungen. 2013. Vol. 114. No. 4. P. 455-472.

2. Cambell A. Old English grammar. Oxford : Clarendon Press, 1968. $423 \mathrm{p}$

3. Carter R. et al. English grammar today. Cambridge : CUP, 2011. $645 \mathrm{p}$.

4. Crystal D. A dictionary of linguistics and phonetics. Malden, MA : Blackwell, 2008. 555 p.

5. Eastwood John. Oxford guide to English grammar. Oxford: OUP, 1995. 446 p.

6. Elbourne Paul. E-Type Anaphora as NP-Deletion. Natural Language Semantics. 2001. Vol. 9(3). P. 241-288.

7. Evans Gareth. Pronouns. Linguistic Inquiry. 1980. Vol. 11(2). P. 337-362.

8. Gramley Stephen. Introduction to Old English. Amsterdam, Philadelphia : Routledge, 2019. 438p.

9. Hogg Richard. An Introduction to Old English. Edinburgh : Edinburgh University Press, 2002.163p.

10. Jacobs R. A. English syntax. A grammar for English language professionals. Oxford : OUP, 1993. 378 p.

11. Jespersen Otto. The Philosophy of Grammar. Amsterdam, Philadelphia : Routledge, 2011. (1924). 358 p.

12. Katz Jerrold and Postal Paul. An integrated theory of linguistic descriptions. Cambridge Mass, M.I.T., 1964. Pp. xi +178 .

13. Kleiber W., Heuser R. (ed.) Introduction and aparatus.Part 1. Tubingen : Niemeyerr, 2004.

14. .Lyons J. Semantics. Vol.1-2. London; CUP, 1977. Vol. 1. 371 p., Vol. 2, pp. 897.

15. Mauch Hana. Personal pronoun and markedness: An interpretation of grammatically conditioned changes. Studia Anglica Posnaniensia. 1989. XXII. P. 81-90.

16. Mykhaylenko V. V. Functional overview of the second person singular pronoun in "Beowulf. Studia Philologica. 2016. No 2. Issue7. P. 36-43.

17. Novak M. Pronoun prediction with linguistic features and example weighing. Proceedings of the First Conference on Machine Translation. Volume Berlin, Germany, August 11-12, 2016. P. 602-605.

18. Quirk R. et al. A comprehensive grammar of the English language. London : Longman, 2000. $\mathrm{x}+1779 \mathrm{p}$.

19. Portele Yvonne, Bader Markus. Accessibility and Referential Choice: Personal Pronouns and D-pronouns in Written German. Zeitschrift für Sprachwissenschaft. 2019. Vol. 38: Issue 2.

20. Sapir Edward. Language: An Introduction to the Study of Speech. New York : Harcourt, Brace and Company 1921. $125 \mathrm{p}$.

21. Simon Horst J., Wise Hike. Pronouns: grammar and representation. Amsterdam, Philadelphia : Routledge, 2002. $291 \mathrm{p}$.

22. Thavenius Cecilia. Referential Pronouns in English Conversation. Lund : CWK Gleerup, 1983. 194 p.

23. Van Bergen L. Pronouns and Word Order in Old English: With Particular Reference to the Indefinite Pronoun Man. Amsterdam, Philadelphia : Routledge, 2017. 244 p.

24. Van Valin Robert D. Jr. Introduction to syntax. Cambridge : CUP, 2001. 256 p.

25. Von Heusinger Klaus. Reference and representation of pronouns / Ed. Horst J. Simon, Heike Wise. Pronouns: grammar and representation. Amsterdam, Philadelphia : Routledge, 2002. P. 109-136.

\section{МихайЛеНко В. В. ВЗАЄМОДІЯ ІТ-ЗАЙМЕННИКА 3 КОНТЕКСТОМ}

Ця стаття є корпусним аналізом іт-займенника в авторському дискурсі та його взаємодї̈ з контекстом. Тлумачення займенника третьої особи однини у структурі речення, або дискурсу, є найбільш суперечливим явищем. Британський національний корпус визначає його частоту - 1045013 на 100 млн слів в англійській мові, щуо підтверджує нашу гіпотезу про те, що чим вище частота мовної одиниці, тим більша можливість для неї бути допоміжною частиною мови, пор.: частоту неозначеного артикля $а$ - 213 692; частки to - 2565 070, прийменника оп 1914216 тощо. Хоча більшість граматистів вважсають особовий займенник (іt включно) до агтсечастин мови на основі форми, синтаксичної функиїі, лексико-граматичної валентності та особливості 'референційної' функиї̈ it у реченні. Ми вважсаємо, щьо it-займенник має складну функиіональну семантику. Ії актуалізація певної функції залежсить від їі контексту. Без сумніву, число їі функцій також багато в чому залежить від об 'єму інформації та інтуійї вченого. Інтерпретація займенника 3-їособи однини складна та викликає непорозуміння й плутанину, щзо єрезультатом суміщення принципів самих класифікацій та суб'єктивних суджень дослідників. Ми ризикнули ввести принцип еволюиії, що дало можливість вирізнити спільні та відмінні риси контекстів зазначеного займенника. Цілком зрозуміло, щзо для досягнення об'єктивності необхідно провести дослідження займенника у структурі не-професійного (типу художнього) та професійного (типу економічного або юридичного), де існуюча неясність недопустима. Ми вважаємо, щзо іt-займенник має складну функиіональну семантику. А актуалізація зазначеної функиії залежсть від ї̈ контексту. Без сумніву, кількість його функцій багато в чому залежить від об'єму інформачї̈ та інтуйиї вченого.

Ключові слова: займенник «IT», семантично пусте слово, субститут, функція, контекстна семантика, дискурс. 